\title{
Outcomes Post-ICU Admission: What Are We Aiming for?
}

\section{Ariel M. Modrykamien*}

Assistant Professor of Medicine, Pulmonary, Critical Care and Sleep Medicine Division, Creighton University School of Medicine, Omaha, NE 68131

\section{Editorial}

The field of intensive care medicine has been rapidly growing over the last century, particularly over the last two decades. The introduction of protocols to reduce mortality in patients with severe sepsis [1], as well as new strategies of mechanical ventilation to improve survival in patients with the adult respiratory distress syndrome (ARDS) [2], have revolutionized our current practice. An increasing number of studies have focused on strategies to improve short and intermediate-term outcomes, such as mortality during the hospitalization, and up to 180 days post-ICU admission [1-4]. Despite these important contributions, many questions still remain. Is the evaluation of the aforementioned outcomes sufficient to assess our therapeutic success?

Recent reports demonstrated that ICU survivors present a significant number of debilitating long-term complications. Quality of life is particularly affected in patients discharged from medical and surgical ICUs, specifically in subjects with ARDS, prolonged mechanical ventilation, severe trauma, and severe sepsis ${ }^{5}$. Both emotional and physical [6,7] components are involved, affecting return to work, participations in activities of daily living, and creating substantial psychological impairment in their relatives. The development of posttraumatic stress disorder and depression is not uncommon in the former group [8]. Strikingly, patients' disability may last up to 10 years post-ICU discharge, and it is usually associated with significant health care utilization and elevated costs [9].

Neurocognitive dysfunction has been recognized in up to $50 \%$ of ICU survivors, when evaluated one year post-discharge [10]. Notably, studies that have focused on cohorts of patients with ARDS have described a prevalence of cognitive impairment that reaches up to $25 \%$, six years post-ICU dismissal [11]. Despite this astonishing reality, few patients are assessed for cognition impairment after ICU discharge. It is likely that neurocognitive dysfunction may remain undetected, as impairment is often subtle and in certain circumstances affects only few cognitive functions, such as memory [12].

Malnutrition in ICU survivors has been getting attention over the last few years. Taking in consideration that ICU patients usually receive an average of 60 to $80 \%$ of the prescribed enteral energy [13], it is not surprising that subjects with ARDS are often discharge with body weights $18 \%$ lower than their baseline [6].

Advances in patient care bring about reductions in mortality and morbidity. Once these short-term goals are achieved, health care providers should focus on how to avoid (or minimize) longterm disabilities. The development of post-ICU clinics may create the environment in which multidisciplinary teams (composed by intensivists, physical and respiratory therapists, nutritionists, pharmacists, and social workers) become available to assess ICU survivors for the development of the aforementioned complications. Utilization of tools, such as quality of life questionnaires [14], neurocognitive assessment forms [15], and medication reconciliation lists, may identify areas of concern. Timely interventions, such as physical therapy [16], cognitive training [17], and psychiatric involvement may optimize patient care and satisfaction. The time to reassess our aims has come. Whereas reduction in mortality rate remains our main short-term goal; the evaluation, prevention, and treatment of long-term complications should become a new priority.

\section{References}

1. Rivers E, Nguyen B, Havstad S, Resslar J, Muzzin A, et al. (2001) Early goaldirected therapy in the treatment of severe sepsis and septic shock. $\mathrm{N}$ Engl J Med 345: 1368-1377.

2. (2000) Ventilation with lower tidal volumes as compared with traditional tidal volumes for acute lung injury and the acute respiratory distress syndrome. The Acute Respiratory Distress Syndrome Network. N Engl J Med 342: 1301-1308.

3. Bernard GR, Vincent JL, Laterre PF, LaRosa SP, Dhainaut JF, et al. (2001) Efficacy and safety of recombinant human activated protein $C$ for severe sepsis. N Engl J Med 344: 699-709.

4. Wiedemann HP, Wheeler AP, Bernard GR, Thompson BT, Hayden D, et al (2006) Comparison of two fluid-management strategies in acute lung injury. N Engl J Med 354: 2564-2575.

5. Oeyen SG, Vandijck DM, Benoit DD, Annemans L, Decruyenaere JM (2010) Quality of life after intensive care: a systematic review of the literature. Crit Care Med 38: 2386-2400.

6. Herridge MS, Cheung AM, Tansey CM, Matte-Martyn A, Diaz-Granados N et al. (2003) One-year outcomes in survivors of the acute respiratory distress syndrome. N Engl J Med 348: 683-693.

7. Herridge MS, Tansey CM, Matte A, Tomlinson G, Diaz-Granados N, et al (2011) Functional disability 5 years after acute respiratory distress syndrome N Engl J Med 364: 1293-1304.

8. Kross EK, Engelberg RA, Gries CJ, Nielsen EL, Zatzick D, et al. (2011) ICL care associated with symptoms of depression and posttraumatic stress disorder among family members of patients who die in the ICU. Chest 139: 795-801.

9. Unroe M, Kahn JM, Carson SS, Govert JA, Martinu T, et al. (2010) Oneyear trajectories of care and resource utilization for recipients of prolonged mechanical ventilation: a cohort study. Ann Intern Med 153: 167-175.

10. Hopkins RO, Weaver LK, Collingridge D, Parkinson RB, Chan KJ, et al. (2005) Two-year cognitive, emotional, and quality-of-life outcomes in acute respiratory distress syndrome. Am J Respir Crit Care Med 171: 340-347.

11. Rothenhausler HB, Ehrentraut S, Stoll C, Schelling G, Kapfhammer HP (2001) The relationship between cognitive performance and employment and health status in long-term survivors of the acute respiratory distress syndrome: results of an exploratory study. Gen Hosp Psychiatry 23: 90-96.

12. Hopkins RO, Jackson JC (2006) Long-term neurocognitive function after critical illness. Chest 130: 869-878.

13. McClave SA, Sexton LK, Spain DA, Adams JL, Owens NA, et al. (1999) Entera tube feeding in the intensive care unit: factors impeding adequate delivery. Crit Care Med 27: 1252-1256.

14. Dowdy DW, Eid MP, Sedrakyan A, Mendez-Tellez PA, et al. (2005) Quality of life in adult survivors of critical illness: a systematic review of the literature. Intensive Care Med 31: 611-620.

15. Nasreddine ZS, Phillips NA, Bedirian V, Charbonneau S, Whitehead V, et al (2005) The Montreal Cognitive Assessment, MoCA: a brief screening tool for mild cognitive impairment. J Am Geriatr Soc 53: 695-699.

Corresponding author: Ariel M. Modrykamien, Assistant Professor of Medicine Pulmonary, Critical Care and Sleep Medicine Division, Creighton University School of Medicine, 601 N. 30th street, Suite 3820,Omaha, NE 68131, Tel: (402) 4494486; Fax: (402) 280-5256; E-mail: arielmodrykamien@creighton.edu

Received July 17, 2011; Accepted October 17, 2011; Published October 19, 2011

Citation: Modrykamien AM (2011) Outcomes Post-ICU Admission: What Are We Aiming for? J Pulmonar Respirat Med 1:e101. doi:10.4172/2161-105X.1000e101

Copyright: (c) Modrykamien AM. This is an open-access article distributed under the terms of the Creative Commons Attribution License, which permits unrestricted use, distribution, and reproduction in any medium, provided the original author and source are credited. 
Citation: Modrykamien AM (2011) Outcomes Post-ICU Admission: What Are We Aiming for? J Pulmonar Respirat Med 1:e101. doi:10.4172/2161105X.1000e101

16. Storch EK, Kruszynski DM (2008) From rehabilitation to optimal function: role of clinical exercise therapy. Curr Opin Crit Care 14: 451-455.
17. Martin M, Clare L, Altgassen AM, Cameron MH, Zehnder F (2011) Cognitionbased interventions for healthy older people and people with mild cognitive impairment. Cochrane Database Syst Rev 19: CD006220. 